\title{
Analysis of Glycerin Waste in A-Area Sanitary Treatment Facility Material(U)
}

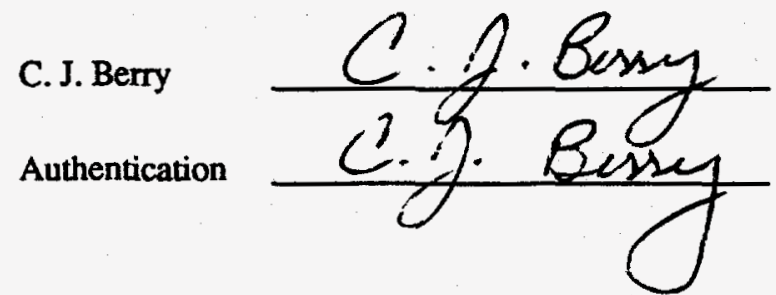

Prepared for the U. S. Department of Energy under contract no. DE-AC09-89SR18035

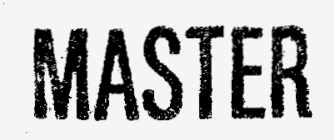




\section{DISCLAIMER}

This report was prepared as an account of work sponsored by an agency of the United States Government. Neither the United States Government nor any agency thereof, nor any of their employees, make any warranty, express or implied, or assumes any legal liability or responsibility for the accuracy, completeness, or usefulness of any information, apparatus, product, or process disclosed, or represents that its use would not infringe privately owned rights. Reference herein to any specific commercial product, process, or service by trade name, trademark, manufacturer, or otherwise does not necessarily constitute or imply its endorsement, recommendation, or favoring by the United States Government or any agency thereof. The views and opinions of authors expressed herein do not necessarily state or reflect those of the United States Government or any agency thereof. 


\section{DISCLAIMER}

Portions of this document may be illegible in electronic image products. Images are produced from the best available original document. 


\section{Analysis of Glycerin Waste in A-Area Sanitary Treatment Facility Material}

\section{Summary}

TNX has a large supply of 55 gallon drums containing pure glycerin and glycerin with additives. The glycerin drums were procured to simulate the glass stream in a pilotscale melter process at TNX. Since the glycerin was not used for this process, TNX is looking at disposing the material in a sanitary waste treatment facility onsite. The effect of adding the contents of the drums to sewage bacteria was tested. A drum of pure glycerin and a drum of glycerin mixed with lithium chloride were tested. The test consisted of mixing sanitary sludge material with the glycerin material. The purpose of the test was to determine if the glycerin impacted the aerobic bacterial population. The bacterial densities were determined by taking samples from the sludge/glycerin mixtures and using aerobic plate count methods. The total organic carbon (TOC) levels were measured before and after testing. The results indicate that the cell density of the aerobic bacteria increased with the addition of glycerin and the glycerin mixture and the TOC removal rate was different for all tests (Figure 1 summarizes the results). Disposal of glycerin in the wastewater treatment facilities should pose no problems. Additional testing and analysis of the mixed samples should be done before its disposal in a waste water treatment facility.

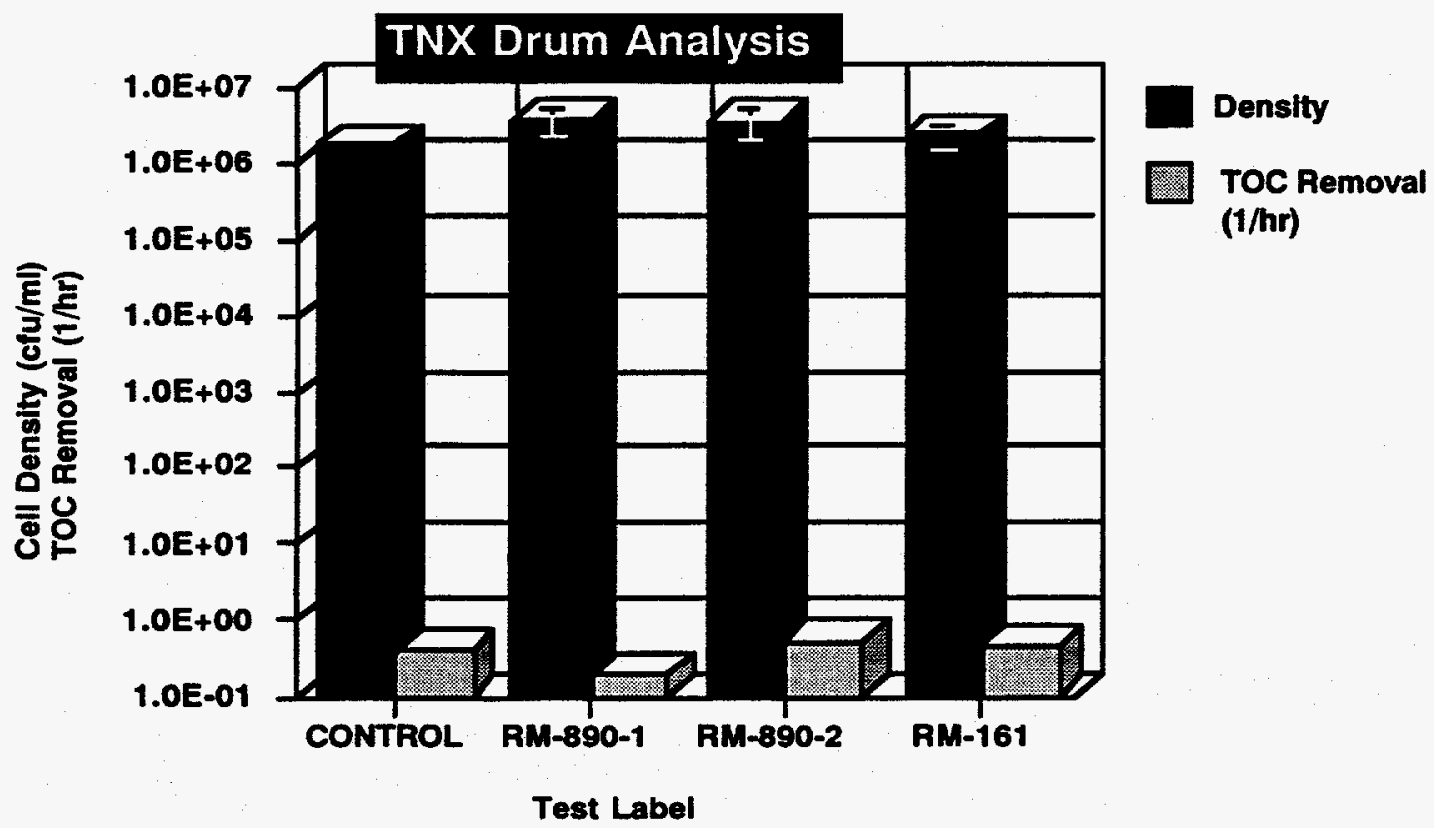

Figure 1. Results of Plate Counts vs. Different Mixtures 


\section{TNX Need}

TNX has twelve 55 gallon drums filled with glycerin, glycerin with water, and glycerin mixed with additives such as lithium chloride. The drums were obtained from an unknown vendor for use with a melter process in 672-T. The glycerin, when mixed with lithium chloride, simulated a glass stream in the process. The glycerin mixtures were not used and the drums remain at TNX. The samples were analyzed for hazardous materials and passed Toxicity Characteristic Leaching Procedure (TCLP Method \#1311, 40 CFR Part 261, Appendix II) testing. However, the waste still needs a method of disposal. TNX wants to use a sanitary waste treatment facility to dispose of the drums. This report summarizes an investigation that examined the impact of the glycerin and glycerin mixtures on waste treatment facility bacteria.

\section{Test Description}

Glycerin was added to sewage sludge material obtained from the A-Area Municipal Waste Treatment Facility's aeration lagoon. The glycerin was obtained from two drums at TNX, RM-890 and RM-161. RM-890 is believed to contain pure glycerin and RM-161 is believed to contain glycerin mixed with lithium chloride. Two concentrations from drum RM-890 and one concentration from drum RM-161 were tested. The RM-890 tests simulated the addition of one and two 55 gallon drums to the A-Area system. This was calculated based on a treatment rate of $67 \%$ of the total system capacity. To simulate one drum being added to the system, a $0.15 \%$ glycerin and sludge solution was used. A $\mathbf{0 . 3 0 \%}$ solution was used to simulate adding two drums; a $0.15 \%$ solution from RM-161 was used.

In the laboratory, sludge and glycerin were mixed in $250 \mathrm{ml}$ Erlenmeyer flasks. After vigorously mixing the flasks, $7 \mathrm{ml}$ samples were placed into sterile $15 \mathrm{ml}$ polyethylene test tubes. Duplicate test tubes were made for each concentration of the glycerin /sludge mixtures. These test tubes were placed in an incubator and shaken with the lids partly ajar to allow air transfer at $30^{\circ} \mathrm{C}$. The aerobic microbial community was enumerated at $\mathbf{4 8}$ hours, an approximate hydraulic retention time of the A-Area system. Aerobic plate counts were used to compare the mixed solution to control samples. At each time point, a $1 \mathrm{ml}$ sample was taken from each of the four test tubes and serial dilutions were made using a sterile fluorescent antibody buffer (FA buffer), a pH adjusted phosphate buffer, as the diluent. The concentrations or the dilutions ranged from $1 \times 10^{-3}$ to $1 \times 10^{-9}$. A one milliliter sample of each dilution was then vacuum filtered on sterile $0.45 \mu \mathrm{m}$ pore diameter filters. These filters are placed on a general nutrient agar within a sterile plastic petri plates. Positive and negative controls were also vacuum filtered and plated. The FA buffer served as a negative control and pure glycerin served as a positive control. The plates were placed in an incubator kept at $27-30^{\circ} \mathrm{C}$ and allowed to grow for $24-48$ hours. ${ }^{1}$ The plates were then examined for

1 Greenberg, A. E., et al., 9215 Heterotrophic Plate Count, Standard Methods for the Examination of Water and Wastewater, 18th ed., 1992. 
colony forming units (CFUs) and counted under a microscope. The CFUs are assumed to develop from a single bacteria, therefore they measure the number of viable aerobic bacteria in a sample that can grow on a general nutrient media. TOC analysis measured the soluble organic carbon. ${ }^{2}$

\section{Analysis}

The CFU counts for each sample were multiplied by the appropriate dilution concentration to determine a cell density in CFU per milliliter of undiluted sample. The negative controls had no significant growth. The positive controls of the glycerin material had a density greater than $1 \times 10^{3} \mathrm{CFU} / \mathrm{ml}$.

\section{Discussion}

The TOC analysis showed a decrease in the soluble carbon content for each test. TOC removal rates were highest in RM-161, RM-890-2. TOC removal rates for RM-890-1 were lower than the control rate.

Testing the sewage sludge material from the lagoon rather than the mixed liquor material makes a difference in glycerin utilization. The sewage sludge material is predominantly made up of cell mass, or flocs of cells, with non-soluble, particulate, or colloidal organic material. The organic loading in lagoons is higher and the cell growth rate is lower than samples from mixed liquor. Mixed liquor contains soluble organics and a mixture of bacteria in a dispersed state. The organic loading is lower and the growth rate of the bacteria is typically higher. Testing the glycerin in a mixed liquor sample may yield different substrate utilization and cell growth rates.

The bacterial density increased and the TOC levels decreased in all of the mixed samples indicating the indigenous organisms utilized the glycerin or the glycerin material as a substrate. The two test samples from RM-890 did not have statistically different cell densities. The TOC removal rate was greater with RM-890-2 indicating the bacteria increased their activity to remove the easily degradable glycerin.

RM-161 contained lithium chloride and possibly other additives. The test results indicate a lower cell density than RM-890 samples. The TOC removal rate was greater than the control sample. This indicates that the sample with the additive was not as stimulating to the bacterial population, as the pure material, but was more stimulating to the bacteria than adding nothing. If the additives remain within the system they could cause problems with consistent sludge wasting although this should not be a problem while treating the glycerin on a per drum basis unless metal accumulated in the sludge.

With pure glycerin samples the carbonaceous oxygen demand of the system would increase. The material does not appear recalcitrant. If process adjustments are made for the increase oxygen demand, there should not be an impact on the effluent stream composition.

2 Greenberg, A. E., èt al, 5310B Total Organic Carbon, Standard Methods for the Examination of Water and Wastewater, 18th ed., 1992. 
As mentioned above, the mixed samples may cause additional problems. Additional analytical tests on the exact composition of the material should be performed. Then, it may be necessary to identify where the additives concentrate within the system.

\section{Conclusion}

The addition of glycerin to samples of sewage bacteria increased the amount of aerobic bacteria over a 48 hour period for two different concentrations and two different samples. The two concentrations tested had higher cell densities than the control, but were not statistically different from each other. The sample with a higher concentration of glycerin had a larger TOC utilization rate. The sample with lithium chloride had a higher cell density than the control, but lower than the tests with pure glycerin. The pure glycerin material should pose no problem being treated in a wastewater treatment facility. Samples with lithium chloride or other additives should be analyzed for metal composition or have further microbial testing prior to treatment. 